LICENÇA CC BY:

Artigo distribuído sob os termos

Creative Commons, permite uso e distribuição irrestrita em qualquer meio desde que o autor credite a fonte original.

\title{
O PAPEL DA REAÇÃO CATÓLICA NA FORMAÇÃO DA NAÇÃO NOS TEMPOS DE CAPANEMA (1934-1945)
}

THE ROLE OF THE CATHOLIC REACTION IN THE DEVELOPMENT OF THE NATION IN THE TIMES OF CAPANEMA (1934-1945) EL PAPEL DE LA REACCIÓN CATÓLICA EN LA FORMACIÓN DE LA NACIÓN EN LOS TIEMPOS DE CAPANEMA (1934-1945)

Celso João Carminati ${ }^{1}$ Aldemir Barbosa da Silva ${ }^{2}$

${ }^{1}$ Doutor em Educação pela UFSC. Docente do Programa de PósGraduação em Educação da Universidade do Estado de Santa Catarina (UDESC), Florianópolis, SC, Brasil.

\author{
${ }^{2}$ Doutorando em Educação pela Universidade do Estado de Santa Catarina
} (UDESC), Florianópolis, SC, Brasil.

\begin{abstract}
Resumo: Este artigo tem como objetivo investigar os indícios do movimento Reação Católica na política educacional do Ministro Gustavo Capanema (1934-1945), após um reposicionamento dos intelectuais entre os órgãos católicos e aparatos estatais, em defesa da cultura católica na formação da nação. Na primeira parte, aborda os indícios da restauração em defesa da pedagogia católica; na segunda, fala sobre a representação de intelectuais católicos nos aparatos estatais, como as articulações no cenário nacional entre as instituições superiores católicas; e, por fim, na terceira parte, apresenta a influência do pensador francês Jacques Maritain entre as produções da revista católica A Ordem e a repercussão do humanismo integral e da democracia cristã em torno do engajamento da militância católica.
\end{abstract}

Palavras-chave: Reação Católica; Intelectuais Católicos; Jacques Maritain.

Abstract: This article investigates the signs of the South American Catholic Reaction movement in the educational policy of Minister Gustavo Capanema (1934-1945), after a repositioning of intellectuals between the Catholic bodies and state apparata, in defense of the Catholic culture in the development of the nation. In the first part, it addresses the defense councils of Catholic pedagogy; in the second, it discusses the representation of Catholic intellectuals in the state apparata, such as the articulations in the national scenario among the Catholic higher institutions; Finally, in the third part, it presents the influence of the French intellectual Jacques Maritain between the productions of the Catholic magazine A Ordem, and the repercussion of integral humanism and Christian democracy around the engagement of Catholic militancy.

Keywords: Catholic Reaction; Catholic Intellectuals; Jacques Maritain.

Resumen: Este artículo tiene como objetivo investigar los indicios del movimiento en América del Sur. Gustavo Capanema (1934-1945), tras un reposicionamiento de intelectuales entre los órganos católicos y los estatutos, en defensa de la cultura católica en la formación de la nación. En la primera parte, los consejos de defensa de la pedagogía católica; en la segunda, 
habla sobre una representación de intelectuales católicos en los aparatos estatales, como las articulaciones en el escenario nacional entre las instituciones superiores católicas; y, por último, en la tercera parte, presenta una influencia del pensamiento nacional Jacques Maritain entre las producciones de la revista católica La Orden y la repercusión del humanismo integral y de la democracia en torno al compromiso de la militancia católica.

Palabras clave: Reacción Católica; Intelectuales Católicos; Jacques Maritain.

\section{Introdução}

Esse texto apresenta uma discussão acerca do papel da Reação Católica na formação da nação nos tempos do ministro Gustavo Capanema (1934-1945), a partir da representação de intelectuais católicos engajados no campo sociopolítico-cultural, entre órgãos católicos e aparatos estatais, fortalecendo as redes de sociabilidade em prol da cultura católica no país.

Essa discussão constitui parte da pesquisa desenvolvida no programa de PósGraduação em Educação, na linha História e Historiografia da Educação da Universidade do Estado de Santa Catarina e, como tal, indica refletir sobre a temática em torno de estratégias católicas no período.

A fundação do movimento Reação Católica na década de 1920 teve por objetivo mobilizar o engajamento de intelectuais eclesiásticos e leigos (laicato católico) na defesa da cultura católica, apontando o papel fundamental da imprensa católica ${ }^{1}$ (sob orientação dos documentos pontífices ${ }^{2}$ ) no projeto de restauração católica ${ }^{3}$, em consonância com a realização de congressos eclesiásticos (Cartas Pastorais) e a fundação das associações, dos movimentos e das ligas católicas (espaços direcionados à militância católica). Tal estratégia católica, com extensão na década de 1930, posiciona intelectuais católicos entre uma rede de autarquias, conselhos, departamentos e comissões especiais no Ministério da Educação e Saúde em torno da formação de alianças com o governo em prol da constituição da nacionalidade 4 .

A imprensa periódica católica atual, para Vilhena (1994, p. 150), funciona "como meio [de] moralizador e saneador dos costumes da sociedade, concomitante ao desempenho do papel de conservação dos princípios e valores norteadores da ética cristã". Nesse viés, a produção, a circulação e os usos dos impressos católicos, além de ocupar espaço privilegiado na formação do laicato católico, constituem um objeto de investigação no campo da História e da Historiografia da Educação, que, ao serem cruzados com outras fontes, sinalizam os indícios da Reação Católica no campo político educacional, como os embates entre intelectuais católicos e escolanovistas.

O intelectual católico, para Sirinelli (2003, p. 248), "organiza-se também em torno de uma sensibilidade ideológica ou cultural comum e de afinidades mais difusas, [...] que fundam uma vontade e um gosto de conviver". Dessa forma, a constituição de princípios 
que possam consolidar uma bandeira pela educação no país se torna objeto de intensas discussões e embates entre os membros da Associação Brasileira da Educação (ABE), os quais provocam novas articulações entre as bancadas pedagógicas. A presença desses membros entre os aparatos estatais (Conselho Nacional da Educação, Comissão Nacional do Livro Didático, Instituto Histórico e Geográfico Brasileiro, Comissão Nacional de Censura Cinematográfica, entre outros) sinaliza o reposicionar no campo político educacional.

No entanto, o engajamento de intelectuais em torno do principal reduto católico - Centro Dom Vital (CDV) - aponta sinais de reestruturação institucional católica ao intensificar a representação dos aportes teórico-filosóficos (católicos) e teológicos entre as discussões, os estudos e as produções editoriais desses intelectuais católicos, como a formação de novas redes de sociabilidade em torno da cultura católica. Nesse caso, os impressos ocupam espaços privilegiados nos avanços da Reação Católica, sendo vinculadas tais produções autorais na principal revista católica do período, A Ordem.

A revista A Ordem - ganha importância, como órgão de difusão das propostas de reordenação do País nos moldes cristãos, agregando intelectuais que se consideram o único segmento da sociedade capaz de oferecer respostas aos problemas nacionais e imprimir novos rumos ao País (RODRIGUES, 2005, p. 16).

A posição estratégica da revista A Ordem (1921) e do CDV (1922), sob lideranças eclesiásticas - Dom Sebastião Leme, Pe. Leonel Franca e o líder católico laico Jackson Figueiredo, pelo viés conservador, e substituído posteriormente por Alceu Amoroso Lima, pelo viés democrático -, permite o expressivo engajamento de intelectuais no projeto de restauração católica. A produção e a circulação de intelectuais entre os periódicos católicos ${ }^{5}$ têm por objetivo divulgar e aprofundar os estudos e as discussões em torno das questões sociais, filosóficas, religiosas, científicas, literárias e políticas pelas lentes da cultura católica. Para Certeau (1994, p. 99), tal posição dos intelectuais católicos, "chamo de estratégia o cálculo (ou a manipulação) das relações de forças que se torna possível a partir do momento em que um sujeito de querer e poder [...] pode ser isolado", ao constituir mecanismos católicos estratégicos em torno da sociedade civil.

A Reação Católica projeta sua restauração pelo viés educacional, com um perfil no quadro institucional eclesiástico de traços definidos, ao mobilizar uma legião de intelectuais em torno da revista A Ordem e do CDV, com objetivo de possibilitar a construção de um pensamento católico no Brasil. A década de $1920^{6}$ e 1930, período de imenso vazio econômico, cultural e político, provoca nas grandes cidades, nos movimentos políticos, culturais e artísticos, com greves operárias, a criação do Partido Comunista Brasileiro, a Semana da Arte Moderna, entre outros movimentos revolucionários que desembocam em soluções populistas ou reformistas. Nesse contexto, o projeto de restauração católica foi liderado por Dom Sebastião Leme (Arcebispo do Rio de Janeiro, 1930-1942), ao organizar, estruturar e aparelhar a reentrada da Igreja na sociedade brasileira no âmbito nacional pela educação (CASALI, 1995). 
O projeto de restauração católica aponta articulações importantes entre a produção, a circulação e os usos dos impressos católicos, e se mostra um instrumento de poder ao instituir a formação da militância católica nos cenários eclesiásticos (arquidioceses, dioceses e paróquias), educacional (instituições tradicionais católicas, leigas e militares, de ensino secundárias ou superiores), político (órgãos católicos ou aparatos estatais) e cultural (artistas e intelectuais).

Para tanto, este artigo está estruturado da seguinte forma: na primeira parte, inquirir aspectos dos avanços da Reação Católica no campo político educacional, em torno do engajamento dos intelectuais na defesa da pedagogia católica; na segunda parte, aborda a representação dos intelectuais católicos na política educacional do ministro Gustavo Capanema (1934-1945) entre a lista dos membros de aparatos estatais, com articulações que projetam as instituições superiores católicas; e, por fim, na terceira parte, discute a influência do pensador francês Jacques Maritain entre as produções da revista católica A Ordem e sua repercussão no projeto de restauração católica.

\section{A Reação Católica na Educação}

Na década de 1930, as articulações do governo no processo de construção institucional permitem acionar as redes de sociabilidade e posicionar intelectuais e artistas em torno de projetos republicanos. Representantes da sociedade civil desempenham funções primordiais como colaboradores, que para Miceli (2001, p. 215), na "política cultural do regime Vargas, aceitando encomendas oficiais de prédios, livros, concertos, manuais escolares, guias turísticos e obras de arte, participando de comissões, assumindo o papel de representação do governo", ocupam posição estratégica na rede de autarquias, conselhos, departamentos e comissões especiais após a abertura de uma série de construções institucionais pelo governo.

A fundação do Ministério da Educação e Saúde Pública (1930) é um marco no governo republicano, pois permite organizar um sistema educacional que universaliza os níveis de ensino e padroniza sua legislação em todo território nacional. Tal posição entre os órgãos federais outorga a função de fiscalizar as instituições públicas e privadas, como financiar ou subsidiar recursos aos programas de ensino. Assim, o objetivo primordial é a formação da identidade nacional brasileira, em defesa dos princípios nacionalistas e republicanos na edificação da cultura nacional.

Nesse viés, as estratégias em torno da política educacional que constituiria a formação da nação brasileira são marcadas por intelectuais engajados entre as bancadas pedagógicas da Escola Nova, com os escolanovistas em defesa das políticas de remodelação da escola e da reforma estrutural dos sistemas escolares, e da escola tradicional, com os católicos em prol do campo teórico e doutrinário da pedagogia católica, resultando em confrontos ideológicos educacionais. No entanto, tais concepções 
pedagógicas articulavam-se como programa de constituição de nacionalidade, sendo estratégico ao governo posicionar tais intelectuais entre os aparatos estatais em defesa da formação da nação (CARVALHO, 2003).

Mesmo com os confrontos ideológicos, os intelectuais mantêm uma posição de engajamento entre o principal reduto da política educacional, a Associação Brasileira de Educação (ABE), a favor dos princípios que regem a bandeira pela educação no país. Tal estratégia, para Certeau (1994, p. 100), é "um tipo específico de saber, aquele que sustenta e determina o poder de conquistar para si um lugar próprio" e possibilita articulações no campo dos debates pedagógicos entre membros da $A B E$ e do governo.

Em 1931, a IV Conferência Nacional de Educação (CNE), além de intensificar os debates educacionais (dualidade do sistema educacional, escola única e laicidade), dá à $A B E$ um status político. Nesse caso, os indícios dessa relação de poder com o governo projetam as discussões do ensino primário, com extensão na reforma do ensino secundário, conforme Schwartzan et al., (2000, p. 207), destinado à "formação do homem para todos os grandes setores da atividade nacional, construindo no seu espírito todo um sistema de hábitos, atitudes e comportamentos", em consonância aos projetos que se entrecruzam no ensino universitário.

As pesquisas no campo da História e da Historiografia da Educação, além de sinalizarem a importância das articulações da $A B E$ na política educacional do país, apontam os confrontos ideológicos entre os representantes educacionais. Nesse sentido, os conferencistas, em 1931, discutem respostas às solicitações do então presidente Getúlio Vargas e Ministro da Educação e Saúde Pública Francisco Campos - ao conceito de educação e como operacionalizá-lo na política educacional. A posição estratégia de Nóbrega da Cunha ${ }^{7}$ na IV CNE, em defesa dos princípios da Escola Nova, desarticula a resposta do líder católico Fernando Magalhães ao governo. Para Carvalho (2003, p. 78), tal manobra "abriu espaço político para o lançamento do Manifesto dos Pioneiros da Educação Nova", como projeção aos próximos encontros da ABE em apresentar os rumos às novas envergaduras na orientação da obra educacional no país.

\footnotetext{
A luz dessas verdades e sob a inspiração de novos ideais de educação, foi que se gerou, no Brasil, o movimento de reconstrução educacional, com que, reagindo contra o empirismo dominante, pretendeu um grupo de educadores, nesses últimos doze anos, transferido do terreno administrativo para os planos político-sociais a solução do problema escolar (AZEVEDO et al., 1932, p. 35).
}

Nessa conjuntura, a representação dos líderes intelectuais escolanovistas ${ }^{8}$, Lourenço Filho, Fernando de Azevedo e Anísio Teixeira, permite novas articulações no campo político educacional, e atuação estratégica em defesa da reestruturação do ensino no país, em torno dos princípios educacionais da Escola Nova ${ }^{9}$ - idealizados pelo filósofo e pedagogo John Dewey. Para Azevedo et al., (2010, p. 33), "na hierarquia dos problemas nacionais, nenhum sobreleva em importância e gravidade o da educação". Dessa forma, a proposta do movimento Escola Nova é organizar a renovação do ensino oficial nas instituições republicanas e possibilitar novos métodos pedagógicos e materiais educacionais. 
Após constatar tais manobras dos intelectuais escolanovistas na IV CNE, em resposta a tal posição, os intelectuais católicos retiram-se da $A B E$ e posicionam-se de forma estratégica na fundação da Confederação Católica Brasileira de Educação $(1933)^{10} \mathrm{e}$ do I Congresso Nacional Católico de Educação (1934). A mobilização dos líderes católicos no campo político educacional permite, assim, reposicionar a pedagogia católica nas instituições tradicionais, bem como fortalecer os laços entre os professores católicos das escolas, dos institutos e das faculdades católicas no período, em consonância com as equipes sociais na fundação da Confederação da Imprensa Católica e da Associação de Livrarias Católicas, impulsionando os impressos católicos na formação cultural da nação.

Na década de 1930, a mobilização eclesiástica em torno do projeto de restauração católica se dá entre o Congresso de Educação do CDV (1931 e 1932), em São Paulo, com objetivo de intensificar os marcos doutrinários da educação católica; o I Congresso Nacional Católico de Educação (1934), no Rio de Janeiro, que irá sinalizar os passos da grande iniciativa educacional católica, pelo Instituto Católico de Estudos Superiores (1932), e o triunfo das emendas católicas na Constituição (1934), frente aos avanços do Manifesto do Pioneiros da Escola Nova (1932); e após a Carta Pastoral do Episcopado Brasileiro (1939), por ocasião do Concílio Plenário Brasileiro no Rio de Janeiro, que aponta que a grande necessidade do Brasil é a formação religiosa, cujas famílias, escolas, colégios, universidade católica, associações católicas e ACB devem caminhar nas diretrizes da cultura católica (CASALI, 1995).

Entre os avanços da Reação Católica, pelo viés ideológico, político e institucional, dá-se a fundação do movimento Ação Católica Brasileira (ACB), em 1935, inspirado no modelo italiano, que aponta entre os principais objetivos o ato de proteger as emendas católicas ${ }^{11}$ obtidas na Constituição de 1934, além de intensificar suas forças de resistência às ideias comunistas no país. Somado ao fato de constituir uma rede de sociabilidade entre instituições católicas (Faculdades Católicas, Congregação Mariana, Círculos Operários, entre outros), a ACB hierarquiza e organiza a juventude militante católica entre os diferentes setores da sociedade civil, articulando novos avanços no projeto de restauração católica.

\footnotetext{
No campo religioso, animou o desenvolvimento da Ação Católica articulando sob sua direção intelectual a organização de uma militância mais ampla por meio de movimentos especializados destinados a aglutinar a juventude na Ação Católica abarcando as cinco vogais: Juventude Agrária Católica (JAC); Juventude Estudantil Católica (JEC); voltada aos estudantes secundários; Juventude Independente Católica (JIC); Juventude Operária Católica (JOC) e Juventude Universitária Católica (JUC), além das organizações dos adultos como os Homens da Ação Católica (HAC) [...] e a Liga Feminina da Ação Católica (LFAC) (SAVIANI, 2011, p. 257).
}

Tal repercussão entre os movimentos da juventude católica tem seus alicerces na Encíclica Urbi Arcano Dei, de 1922, do Papa Pio XI, que prioriza a fundação dos apostolados leigos (militância católica) que possam ter ramificações de evangelização entre as nações católicas, sob direção e hierarquia do poder eclesiástico. No entanto, a posição estratégica da Encíclica Divini Illus Magistri12, de 1929, do Papa Pio XI, em consonância com o projeto de restauração católica, aponta a essência da educação cristã 
com orientações à Igreja, à família e ao Estado, sinalizando a importância suprema da educação cristã na formação da nação. Nesse viés, ao posicionar intelectuais católicos ${ }^{13}$ entre as instituições tradicionais do país em prol da pedagogia católica, sinaliza indícios de restauração católica na política educacional, conforme Carvalho (2003, p. 96), ao "construir um discurso escolanovista católico que ganhasse a adesão do professorado". Tais intelectuais, ao se engajarem no projeto de restauração, organizam uma rede de sociabilidade que permite fortalecer a presença dos professores católicos na formação da nação em torno da Associação dos Professores Católicos (APCs).

As APCs, além de denunciarem os excessos da pedagogia moderna (Escola Nova), utilizam os impressos católicos, como os boletins, para convocar os professores em defesa da pedagogia católica, sinalizando resistência às ideias do pragmatismo, do experimentalismo, do industrialismo, do democratismo, do imanentismo, do naturalismo e do socialismo, que foram consideradas para Carvalho (2003, p. 33) "tendências doutrinárias a serem expurgadas do credo pedagógico do professorado católico".

À primeira vista, o fio condutor no campo dos debates pedagógicos é a desarticulação dos intelectuais católicos na ABE e o posicionamento dos intelectuais escolanovistas a partir do Manifesto. Tal ruptura provoca articulações no projeto de restauração católica, as quais intensificam o engajamento do laicato católico entre os órgãos católicos que foram hierarquizados e organizados pelos documentos pontífices em torno do papel da Reação Católica na formação da nação.

\section{Intelectuais no Tempo de Capanema}

Na década de $1930^{14}$, a educação configura-se uma área estratégica e a mobilização da Igreja Católica em torno da formação da nação representa o posicionar contra a laicização do ensino, da cultura, dos sindicatos e do Estado. Nesse caso, projetar a Liga Eleitoral Católica (LEC) na Assembleia Constituinte aponta um compromisso do laicato em defesa da cultura católica. As alianças entre o poder eclesiástico e o poder estatal ocorrem com o Ministro da Educação e Saúde Francisco Campos ${ }^{15}$, pelo Decreto n ${ }^{0} 19.941$ de 30 de abril de 1931, que autoriza o ensino religioso nas escolas públicas e, depois, com o ministro Gustavo Capanema ${ }^{16}$, com aprovação das emendas religiosas, em 1934, prevendo a invocação do nome de Deus no preâmbulo do anteprojeto constitucional e o restabelecimento da colaboração entre a Igreja Católica e o governo.

A posição católica estratégica na versão final da Constituição de 1934 é indício do reposicionar no campo sociopolítico-cultural em torno do projeto de restauração católica. Entre as disposições institucionais nos tempos de Capanema (1934-1945), dá-se a presença de intelectuais católicos entre os membros dos aparatos estatais e as articulações entre as instituições tradicionais católicas, leigas e militar de ensino secundário e superior. 
Com efeito, a facção que historicamente vem conseguindo manter o seu lugar no órgão consultivo máximo do setor educacional e que mais ganhos consegue com a reforma de 1936 é a dos católicos militantes. Tendo ampliado para dois membros a presença da Igreja em 1935, consegue aumentá-la agora para quatro representantes, o que corresponde a $25 \%$ do total de conselheiros. Além disso, é preciso considerar a posição estratégica que esse grupo vem ocupando há muitos anos na máquina burocrática interna, com Américo Jacobina Lacombe, que ocupa o cargo de secretário do conselho desde 1931 (MICELI, 2001, p. 306).

Tais articulações permitem ao governo manter a função de instância reguladora e organizadora do desenvolvimento capitalista e utilizam os aparatos estatais para a formação do espírito nacionalista, com intuito de consolidar e legitimar a constituição do Estado soberano. Nesse caso, entre as importantes intervenções do governo, ocorrem alianças nos campos político e religioso na sociedade civil, além de posicionar intelectuais católicos entre os membros de aparatos estatais, que formam ofensivas contra os avanços da tendência política-ideológica comunista no país.

Nesse viés, os órgãos católicos e a imprensa periódica católica são posicionados em detrimento aos avanços da tendência política-ideológica comunista, que inflamam sindicatos, partidos, associações e intelectuais. Tais alianças com o governo representam indícios do poder católico ao reposicionar sua atuação no campo sociopolítico-cultural na construção de um Estado-Nação forte e bem constituído. Nesse caso, a Igreja Católica, como um setor organizado da sociedade, posiciona os líderes católicos Alceu Amoroso Lima $^{17}$ e Pe. Leonel Franca S. J. ${ }^{18}$ entre articulações estratégicas com o então Ministro da Educação e Saúde Gustavo Capanema.

Nas décadas de 1930 e 1940, é oportuno destacar que o regime Vargas soube buscar e incentivar no imaginário coletivo o suporte para a sua legitimação e, para isso, tratou de estabelecer alianças com diversos setores da sociedade, inclusive com a Igreja Católica - a qual já buscava uma maior aproximação com o Estado. [...] Portanto, a aproximação entre fé e poder garante a este o acesso a imagens e símbolos religiosos. Os auxílios prestados pela Igreja Católica foram de duas ordens: primeiro no campo político, e segundo no campo da domesticação das consciências, tendo como ponto comum entre ambos o combate à luta de classes (RODRIGUES, 2005, p. 15).

Nos campos político e da domesticação das consciências, o governo utiliza a posição estratégica da Igreja Católica para construir diques contra as propostas ideológicas adversas às suas. Nesse viés, tal estratégia Certeau (1994, p. 102) diz que "são, portanto, ações que, graças ao postulado de um lugar de poder [...], elaboram lugares teóricos [...] capazes de articular um conjunto de lugares físicos onde as forças se distribuem", ou seja, tais articulações permitem ao aparato estatal a manutenção dos princípios nacionalistas e republicanos e, aos órgãos católicos, possibilitam intensificar a formação da militância e da ação nas políticas educacionais entre as instituições tradicionais de ensino secundário ${ }^{19}$ e superior. Nesse projeto, os impressos católicos ocupam espaço privilegiado, pois a produção (de revistas, boletins, livros, livros didáticos, jornais, entre outros), a circulação (em espaços eclesiásticos, instituições de ensino católico e nos órgãos católicos entre as arquidioceses, dioceses e paróquias) e a apropriação ${ }^{20}$ (militância leiga e eclesiástica) dos princípios da cultura católica se tornam instrumentos na organização e na participação efetiva do laicato católico no 
país. Entre os redutos institucionais onde circulam os impressos católicos, destacam-se as Faculdades Católicas, o Instituto Católico de Estudos Superiores (ICES) e a Confederação Católica Brasileira de Educação (CCBE), com extensão na Associação dos Universitários Católicos (AUC), espaço privilegiado na formação da elite, bem como sua relação intrínseca com os princípios da cultura católica.

As redes de sociabilidade da Igreja Católica no campo político educacional possibilitam a fundação das Faculdades Católicas ${ }^{21}$ e da Pontifícia Universidade Católica (PUC-RJ), dando estrutura à formação das elites católicas e, para Campos (2005, p. 176), "visando formar uma elite intelectual que fosse capaz de dar sustentação teórica ao projeto de romanização".

A posição de tais instituições na formação da nação, para Chartier (2011, p. 16), aponta que "sempre a representação das práticas tem razões, códigos, finalidades e destinatários particulares. Identificá-los é uma condição obrigatória para entender as situações ou práticas". Nesse viés, a representação católica entre as novas instituições superiores sinaliza articulações na aprovação do Plano Nacional de Educação, sendo indícios intrínsecos de compromissos na aliança com o governo.

O percentual de representação da Igreja é tanto mais significativo quando se sabe que, entre os porta-vozes do ensino superior tradicional, "os rachas" são muito mais frequentes, que é muito mais baixa a coesão ideológica e política entre as demais facções e, ainda mais, quando se sabe que as tomadas de posição da ala católica encontram, em seu favor, o apoio dos empresários particulares do ensino, e entre eles um dos principais é a própria Igreja e suas ordens religiosas (MICELI, 2001 p. 307).

Tais articulações entre as políticas educacionais possibilitam ao movimento $A C B$ posicionar-se entre os centros universitários, recrutando a juventude católica no engajamento no projeto de restauração católica. Esse projeto é orientado por lideranças católicas conforme orientações dos documentos pontífices, em torno do pensamento filosófico católico. Tais saberes passam a ter circulação entre os principais impressos, como nas revistas católicas A Ordem, Verbum e Kriterion e nos boletins das APCs.

Na Universidade Católica do Rio de Janeiro a tradição de Leonel Franca preserva sobre tudo através da revista "Verbum", dirigida pelo P. Francisco Leme Lopes, S.J. [...] a revista "A Ordem", órgão do Centro, tem acolhido trabalho de valor de jovens tomistas. [...] Artur Versiani Velloso, professor da Faculdade Filosofia da U.M.G e fundador da revista "Kriterion" da mesma Faculdade (FRANCA, 1978, p. 365-366).

Os impressos católicos representam um mecanismo de poder, pois sua produção, circulação e seus usos percorrem a formação da elite em consonância com a formação dos líderes e da militância católica, sendo estratégica sua posição entre os centros acadêmicos no país, pois tais materiais são propícios às discussões em torno dos pensadores das matrizes político-ideológicas (pelo viés, conservador e antirrevolucionário - Edmund Burke, De Bonald, De Maistre, e Donoso Cortés), e das matrizes teórico-filosóficas (pelo viés, democrático - Carl Schmitt, Henri-Louis Bergson, e Jacques Maritain). Nesse viés, o pensador francês Jacques Maritain tem posição privilegiada entre as discussões da filosofia católica nos principais órgãos católicos do país. 
Dessa forma, a posição estratégica do laicato católico nos tempos de Capanema, além de articular os membros da LEC entre os avanços das emendas católicas, permite o engajamento da militância católica e fortalece a representação dos impressos católicos na formação da nação. As alianças entre a Igreja Católica e o Estado são pontos estratégicos na consolidação de um Estado-Nação soberano em detrimento aos avanços do comunismo no país.

\section{O Pensamento Maritainiano na Revista A Ordem}

Ao inquirir a trajetória do pensador francês Jacques Maritain 22 (1882-1972), representante das correntes filosóficas neoescolástica e neotomista e defensor dos preceitos do humanismo integral e da democracia cristã, tais temas apontam aportes teóricos em prol da cultura católica em torno das questões metafísicas frente aos imperativos das ciências positivistas. Nesse viés, na década de 1930, as produções acerca do pensamento maritainiano ocupam espaço na revista A Ordem com ampla circulação entre os órgãos católicos CDV, LEC, APCs, Sociedade Jurídica Santo Ivo (SJSI) e instituições ligadas à $A C B$, constituindo-se arcabouços teórico-filosóficos católicos.

A principal influência do filósofo francês Jacques Maritain dá-se por Alceu Amoroso Lima (Tristão de Ataíde, pseudônimo do crítico literário), líder do laicato católico e do CDV (considerado o principal reduto teórico dos católicos). Tal posição estratégica entre os órgãos católicos permite manobras no cenário nacional, como reposicionar os intelectuais católicos entre os aparatos estatais na defesa de princípios cristãos e republicanos, em consonância com os interesses do governo. Nesse caso, a relação de poder entre Igreja Católica e Estado no período pós-guerra marca uma aliança em detrimento aos avanços da tendência política-ideológica comunista no país.

\footnotetext{
Tristão de Ataíde trouxe para o Brasil o pensamento de Maritain, as posições político-sociais maritainianas do "humanismo integral". Esse livro de 1936, obra prima da filosofia social de Maritain, publicado em plena Revolução Espanhola e escrito originariamente para o curso de verão da universidade de Santander, na Espanha, em 1935, esse livro pioneiro teve enorme repercussão no pensamento católico do Brasil. Foi um impacto. Foi um divisor de águas. Separou fundamente. Suscitou divergências terríveis. A partir daí, o pensamento católico brasileiro se diversifica: os maritainianos e os antimaritainianos. Os reacionários e os liberais. Os abertos e os fechados. Os da direita e os da esquerda. O passado e o presente (VILHAÇA, 2006, p. 16).
}

O humanismo integral constitui os princípios cristãos de liberdade, solidariedade e justiça, pois representa uma nova cristandade, ou seja, o homem integral dá-se na relação do humanismo teocêntrico, que não distingue o cristão e o não cristão, mas reconhece a importância de um regime pluralista com base na democracia cristã, em oposição ao humanismo antropocêntrico, no qual o homem é o homem da burguesia, abstrato, amputado, rasteiro, ou seja, individual. Ao investigar os sinais do humanismo integral, é possível reconhecer os fundamentos da filosofia cristã entre as discussões que inflamam os católicos europeus e os aportes teóricos para estruturar as novas produções 
acadêmicas entre institutos, faculdades e universidades católicas do país. O filósofo francês é considerado um dos pilares teórico-filosóficos neotomista na América Latina, por influenciar o engajamento de intelectuais católicos em torno do humanismo integral, com a fundação do partido Democrata Cristão Latino Americano, com expressivo impacto entre os governos da Venezuela e do Chile.

\footnotetext{
O filósofo católico Jacques Maritain representou uma nova voz do neotomismo dentro da Igreja Católica no século XX, mais precisamente a partir da década de 1930, procurando romper com a crítica simples ao mundo moderno. Jacques Maritain, que até 1926 condena o mundo moderno e está vinculado à Action Française, vai propor, a partir de 1927, que se tomem como válidas as contribuições da modernidade, mas que sejam colocadas em favor de uma nova sociedade, ao mesmo tempo unitária e pluralista. Essa sociedade deveria ter esse teor em razão da necessidade de formar-se por meio de uma pluralidade de confissões de fé e de posicionamentos políticos - inclusive aqueles não católicos - mas sob inspiração cristã católica. Jacques Maritain exerceu influência nos meios intelectuais católicos no Brasil e de forma semelhante em partes da Europa e também em partes da América Latina (RODRIGUES, 2006, p. 15).
}

A influência do pensamento maritainiano entre os autores da imprensa periódica católica aponta a presença da filosofia católica neotomista. Para Japiassu e Marcondes (1996, p.174), isso significa "instaurar uma metafísica cristã que, ao afirmar o primado da questão ontológica sobre a gnoseológica, permitisse evitar os erros e os desvios aos quais sucumbira o idealismo moderno". Nesse viés, constitui um dos pilares teórico-filosóficos no campo da arte, da política e da metafísica após estruturar as bases epistemológicas da fé católica em detrimento das ciências positivistas. o pensador francês propõe uma nova via como a verdadeira revolução a empreender sob o signo de uma filosofia cristã em torno da integração de todas as realidades materiais e espirituais que possam estar em consonância com as discussões ontológicas e sociológicas.

Essa revelação da verdade total representava também uma reintegração do espírito de dinamismo revolucionário das instituições de uma sociedade injusta na reforma do regime político; na ascensão social das classes populares; na reabilitação da democracia; no fim do reino da plutocracia e, portanto, do capitalismo liberal; na liberdade como uma pedra fundamental da cidade humana, ao lado da justiça (PUSSOLI; LIMA, 1995, p. 40).

A representação de Jacques Maritain entre os intelectuais católicos da América Latina, além de posicionar-se em defesa da democracia cristã e do humanismo integral, expõe a necessidade do engajamento dos cidadãos em torno das questões sociais, na defesa dos princípios de justiça e liberdade e na constituição de um governo democrático, em detrimento ao humanismo antropocêntrico, inclinado às formas de governos totalitaristas.

Além da presença autoral em inúmeras obras ${ }^{23}$, há produção do pensador francês entre os artigos da revista A Ordem: O doutor Commum (1929); Sobre a sabedoria agostiniana I - II (1930); Freudisme et psychanalyse (1937); Os pontos nos "ii" (1939); e o Crepúsculo da civilização (1939). Aqui, é importante salientar a presença de Jacques Maritain no CDV (Rio de Janeiro), em 1936, e articulações nesse órgão católico em prol da cultura católica na América Latina. Além da publicação da entrevista de Jaques Maritain pela redação da revista A Ordem em $1937^{24}$, ele foi 
homenageado pelo CDV. Entre os artigos sobre o autor, constam: Jacques Maritain mensageiro da Idade Nova (1937); O sentido da obra de Jacques Maritain (1946); e uma edição especial da revista A Ordem, em 1946.

\begin{abstract}
A revista "A Ordem" do Rio de Janeiro publicou em 1946 um número especial tirado em separata, com mais de trinta artigos sobre suas obras. Pode-se dizer que não passa uma semana sem que seu nome seja citado nos jornais. O trabalho bibliográfico para as teses de concursos que não tardarão a ser publicadas sobre Maritain na América deverá ser considerável e nunca será completo, pois a imprensa das províncias de todo continente, onde é muito mais difícil de pesquisar as referências, não fica atrás dos interesses que a imprensa das grandes capitais vêm mantendo pelo filósofo do humanismo integral (PUSSOLI; LIMA, 1995, p. 54).
\end{abstract}

As discussões sobre a concepção cristã do homem, expressas no livro Rumo da Educação, abalizam o reatar da tradição medieval pelo trivium e quadrivium na formação da nação, como a denúncia ao humanismo renascentista pela inclinação aos clássicos poetas romanos e gregos Virgílio e Homero em detrimento aos saberes da metafísica e aos documentos eclesiásticos. Assim, a concepção cristã do homem é distanciada dos preceitos da metafísica materialista, do positivismo e do ceticismo.

A concepção filosófica e religiosa do homem se apresenta sob vários aspectos. Se afirmo que a educação bem baseada é a que se baseia na concepção cristã, é por ser esta a única verdadeira e não por parecer-me a civilização atual impregnada dela. Além do mais, o homem da nossa civilização é o homem cristão, mais ou menos secularizado. Por conseguinte, devemos aceitar esta ideia como base comum e deduzir que o mesmo acontece na consciência comum dos povos civilizados. Exceto entre aqueles que aderiram a pontos de vista extremadamente opostos, como a metafísica materialista, o positivismo, o cepticismo (MARITAIN, 1947, p. 21).

Na mesma esteira, as discussões sobre democracia cristã, expressas no livro Cristianismo e Democracia, evidenciam a necessidade de pensar uma política com traços da democracia realista, que possa universalizar os interesses comuns entre católicos e não católicos e que possibilite a supremacia da liberdade, da igualdade e da fraternidade impetrada na Revolução Francesa. As políticas totalitaristas apontam perigos para a democracia por se inclinarem ao antropocentrismo e não reconhecerem aspectos fundantes para a restauração da democracia entre os preceitos do teocentrismo.

O cristianismo representa a verdadeira democracia, fornecendo-lhes as suas raízes autênticas. $E$, por outro lado, o que a democracia, neste século, pode representar para o Cristianismo, como instrumento político de defesa da Liberdade contra a perpetuação do Totalitarismo, sob outras máscaras, sobretudo a comunista, e como meio de organização de uma Nova Cristandade, em que os valores essenciais sejam preservados para que haja mais justiça entre os homens na sociedade futura (MARITAIN, 1945, p. 10).

Inquirir as discussões do pensador francês em torno da educação e da democracia aponta um instrumento estratégico para o projeto de restauração católica a partir de preceitos democráticos que possibilitam constituir os pilares educacionais pelo humanismo integral. Nesse caso, os intelectuais católicos apropriam-se do pensamento maritainiano em defesa dos princípios da cultura católica na nação brasileira e reposicionam-se entre os órgãos católicos e aparatos estatais, em consonância com os interesses da Igreja Católica e do Estado na formação da nação. 


\section{Algumas Considerações}

Este artigo se propôs a discutir o papel da Reação Católica na política educacional do ministro Gustavo Capanema ao posicionar-se de forma estratégica no campo sociopolíticocultural. A defesa da pedagogia católica ocupa espaço privilegiado no projeto de restauração católica, sendo imprescindível a intervenção de intelectuais católicos entre as discussões na $A B E$, e atuação nos aparatos estatais e órgãos católicos em prol da cultura católica na formação da nação. As redes de sociabilidade que compõem a estrutura do governo permitem intensificar o projeto da construção institucional, sendo primordial manter aliança com a Igreja Católica por reconhecê-la como setor organizado da sociedade e importante instrumento na construção de um Estado Nação forte e bem constituído.

Nessa conjuntura, entre os avanços do projeto de restauração católica, além do fortalecimento do reduto católico, o CDV e a revista A Ordem, ocorrem manobras em torno da fundação dos órgãos católicos APCs, SJSI, ACB (formada por instituições interligadas) e LEC, responsável pela aprovação de emendas religiosas na Constituição Federal de 1934. Nesse viés, a representação católica no cenário nacional, em torno das alianças estratégicas de líderes católicos com o governo, possibilita intensificar a construção de barreiras contra o advento dos princípios do comunismo na nação. A relação entre produção, circulação e apropriação dos impressos católicos configura pontos estratégicos ao reposicionar no campo editorial (revistas, jornais, boletins, livros didáticos ou pedagógicos, livros de proselitismo, entre outros), pois compõe as estruturas do saber na fundação das bibliotecas pedagógicas católicas e nas instituições católicas (colégios, institutos, faculdades e universidades).

A extensão dos impressos católicos nos cenários acadêmicos (cursos, congressos, seminários e simpósios) possibilita reconhecer sinais da influência do pensamento do filósofo francês Jacques Maritain entre os aportes teórico-filosóficos do neotomista na defesa do humanismo integral, como os fundamentos que estruturam a restauração de uma sociedade católica, compostos por princípios democráticos. Assim, é primordial o engajamento dos cristãos em torno desse projeto, sendo imperativo reconhecer os fundamentos da filosofia a partir da renascença escolástica no século XIX pelas questões vitais do pensamento aristotélico e neotomista.

A análise aqui apresentada demonstrou o papel da Reação Católica na formação da nação nos tempos Capanema (1934-1945). A presença de intelectuais católicos, na $A B E$, nos aparatos estatais do Ministério da Educação e Saúde e na aprovação das emendas católicas na Constituição 1934, entre outros, é indício da representação da cultura católica na formação da nação. A estruturação dos órgãos católicos foi alicerce para o projeto de restauração católica, pelo viés da educação, e sua posição em torno das instituições tradicionais católicas, militares e leigas (secundárias e superiores) aponta um poder estratégico pelos impressos católicos. 


\section{Referências}

A ORDEM. Entrevista de Jacques Maritain. A Ordem. Ano XVII, v. 18. Rio de Janeiro. jul/dez, 1937, p. 11-15.

AZEVEDO, Fernando de. et al., Manifesto dos Pioneiros da Educação Nova (1932) e dos educadores (1959). Recife: Massangana, 2010.

CAMPOS, Névio de. A presença do laicato católico no Paraná nos anos de 1920 e 1930. História: Questões \& Debates, Curitiba, n. 43, p. 169-182, 2005.

CARVALHO, Marta M. C. de. A escola e a República e outros ensaios. Bragança Paulista: EDUSF, 2003.

CASALI, Alípio. Elite Intelectual e restauração da Igreja. Petrópolis, RJ: Vozes, 1995.

CERTEAU, Michel de. A invenção do cotidiano. 14ª Ed. Petrópolis, RJ: Vozes, 1994.

CHARTIER, Roger. Cultura escrita, literatura e história. Porto Alegre: ARTMED, 2001.

Defesa e ilustração da noção de representação. Fronteira, Dourado, MS, v. 13, n. 24, p. 15-29, jul/dez. 2011.

CURY, Carlos Roberto Jamil. Alceu Amoroso Lima. In. FÁVERO, Maria de Lourdes de Albuquerque, BRITTO, Jader de Medeiros. Dicionário de Educadores do Brasil. Rio de Janeiro: URFJ/MEC Inep, 1999.

DALLABRIDA, Norberto. O MEC-INEP contra a Reforma Capanema: renovação do ensino secundário na década de 1950. Perspectiva, Florianópolis, v. 32, n. 2, 407-427, mai/ago, 2014.

FÁVERO, Maria de Lurdes de Albuquerque; BRITTO, Jader de Medeiro. Dicionário de Educadores no Brasil. Rio de Janeiro: Ed. UFRJ/MEC-Inep, 1999.

FILHO, Fernando Antonio Pinheiro. A invenção da ordem Intelectuais Católicos no Brasil. Tempo Social, v. 19, n. 1, p. 33-49, jun. 2007.

FRANCA, Leonel. Noções de História da Filosofia. 22ª Ed. Rio de Janeiro: Agir, 1978.

JAPIASSÚ, Hilton; MARCONDES, Danilo. Dicionário Básico de Filosofia. $3^{a}$ Ed. Rio de Janeiro: Jorge Zahar, 1996.

MARITAIN, Jacques. Rumos da Educação. Rio de Janeiro: Agir, 1947.

. Cristianismo e Democracia. 2a Ed. Rio de Janeiro: Agir, 1945.

MICELI, Sérgio. Intelectuais à brasileira. São Paulo: Companhia das Letras, 2001.

PUSSOLI, Lafaiete; LIMA, Jorge da Cunha (org.). Presença de Maritain: testemunhos. São Paulo: LTr, 1995.

RODRIGUES, Cândido Moreira. A Ordem: uma revista de intelectuais católicos (1934-1945). BH, Autêntica/FAPESP, 2005. 
Alceu Amoroso Lima: matrizes e posições de um intelectual católico militante em perspectiva histórica - 1928-1946. 2006. Tese (Doutorado em História) Faculdade de Ciências e Letras de Assis - UNESP.

SAVIANI, Dermeval. História das ideias pedagógicas no Brasil. $3^{a}$ Ed. Campinas, SP: Autores Associados, 2011.

O legado educacional do século XX no Brasil. In: SAVIANI, Dermeval et al., $\mathbf{O}$ legado educacional no século XX no Brasil. São Paulo: Autores Associados, 2017.

SCHWARTZMAN, Simon; BOMENY, Helena M. B; COSTA, Vanda M. R. Os tempos de Capanema. São Paulo: Paz e Terra: FGV, 2000.

SIRINELLI, Jean-François. Os intelectuais. In: RÉMOND, René. Por uma história política. $2^{a}$ Ed. RJ: Editora FGV. 2003.

VELLOSO, Mônica Pimenta. A Ordem. Uma revista de doutrina política e cultura católica. Revista de Ciências Política. v. 21, n. 3, p. 117-160, jul/set. 1978.

VILHAÇA, Antônio Carlos. O pensamento católico no Brasil. Rio de Janeiro: Civilização Brasileira, 2006.

VILHENA, Cynthia Pereira de Sousa. Imprensa e educação católicas na formação do público leitor feminino (1920/1950). Projeto História. São Paulo (11). nov. 1994.

Artigo recebido em: 01/02/2019 Aprovado em: 06/06/2019

\section{Contato para correspondência:}

Aldemir Barbosa da Silva.E-mail: maquiavel.sc@hotmail.com

Notas

1 A imprensa católica se intitulava portadora da boa mensagem, pois pregava que "a boa leitura preserva dos múltiplos erros que envenenam as almas incautas, orna de conhecimentos a inteligência, fortalece a vontade para o bem, robustece a fé, alenta a esperança num prêmio eterno e inflama a caridade para com Deus e para com o próximo; mostra, em uma palavra, o verdadeiro caminho que se deve trilhar" (CAMPOS, 2005, p. 174).

2 Encíclicas, Cartas Apostólicas, Exortação Apostólica, Discurso, Homilias, Constituição Apostólica, Motu Proprio (normativas da Igreja Católica), entre outros.

3 Os indícios do projeto de restauração da Igreja Católica ocorrem após o Concílio Plenário Latino-Americano em 1898, sendo convocados representantes eclesiásticos das Igrejas dos países da América Latina na organização de Conferências episcopais periódicas, que permitissem recuperar o desenvolvimento organizacional da Igreja, e atuação nos campos político e cultural, com objetivo da formação de um Partido Católico e uma Universidade Católica (CASALI, 1995).

4 A constituição da nacionalidade deveria ser a culminação de toda a ação pedagógica do ministério em seu sentido mais amplo. É possível distinguir pelo menos três aspectos neste esforço de nacionalização. Primeiro, haveria que dar conteúdo nacional à educação 
transmitida nas escolas e por outros instrumentos formativos [...]. O segundo aspecto era, precisamente, a padronização [...]. O terceiro aspecto, finalmente, era o da erradicação das minorias étnicas, linguísticas e culturais que se haviam constituído no Brasil nas últimas décadas, cuja assimilação se transformaria em uma questão de segurança nacional (SCHWARTZMAN et al., 2000, p. 157-158).

5 Entre outros periódicos católicos que circulam no Rio de Janeiro, São Paulo e Paraná, na década de 1920 a 1930, destacam-se as revistas: Vozes de Petrópolis; A Família Cristã; A Ordem; Brasileira de Pedagogia; Ação Católica; Juventude; Leitores e Livro; Alvo; A Cruzada; Cruzeiro e O Luzeiro, sendo objetos estratégicos para o engajamento do laicato católico na formação de importantes lideranças entre os órgãos católicos com objetivo de restauração da Igreja Católica (VELLOSO, 1978).

6 Nesse período, o projeto de restauração católica entre os congressos eclesiásticos e os documentos pontífices, resulta: em 1922, na Carta pastoral do centenário da independência, lamenta a separação Igreja-Estado (1890) e defende a educação em particular a educação religiosa; e após, em 1929, a Encíclica Divini Illius Magistri foi marco estratégico para as novas iniciativas da Igreja no campo educacional. Mas, nas décadas anteriores, ocorrem movimentações importantes no cenário católico nacional, como: em 1900, o I Congresso Católico Brasileiro realizado em Salvador; em 1901, o I Congresso Diocesano em São Paulo; em 1904, II Conferência dos Bispos da Província Eclesiástica de São Sebastião no Rio de Janeiro; em 1908, o II Congresso Católico Brasileiro; em 1910 e 1915, a Carta Pastoral Coletiva em São Paulo; e após, em 1916, a Carta Pastoral com D. Sebastião Leme (anúncio do movimento de restauração católica no país). Entre os objetivos específicos, constam: a fundação das associações católicas nas dioceses; a fundação da imprensa católica; a criação da protetora do ensino cristão; a defesa da instrução católica nacional; a fundação das escolas católicas e faculdade de filosofia e letras; entre outros (CASALI, 1995).

7 Integrou o quadro de associados da Associação Brasileira de Educação desde 1928 e, a partir de 1930, tornou-se membro da Associação Brasileira de Imprensa. Como já se mostrou, teve papel decisivo na articulação do processo que desembocou na redação de divulgação do "Manifesto dos Pioneiros da Educação Nova" (SAVIANI, 2011, p. 239).

8 Lourenço Filho, diretor-geral do Ensino Público de São Paulo na década de 1930); Fernando de Azevedo, ex-diretor da Instituição Pública do Distrito Federal (1926-1930) e, mais tarde, presidente da ABE e diretor da Instituição Pública do Estado de São Paulo (1933); e Anísio Teixeira, então diretor da Instituição Pública do Distrito Federal (19311934) e, depois, secretário de Educação da Bahia.

9 O manifesto dos Pioneiros da Educação Nova pode, pois, ser considerado um importante legado que foi deixado pelo século XX. É um marco de referência que inspirou as gerações seguintes, tendo influenciado, a partir de seu lançamento, a teoria da educação, a política educacional, assim como a prática pedagógica em todo país. [...] As diretrizes e as posições firmadas no Manifesto fizeram-se sentir nos debates da Constituinte de 1933-1934, influenciando o texto da Constituição de 1934, cujo artigo 150, alínea "a", estabelece como competência da União "fixar o plano nacional de educação, compreensivo do ensino de todos os graus e ramos, comuns e coordenar e fiscalizar a sua execução, em todo o território do país" (SAVIANI, et al., 2017, p. 44).

10 Em fevereiro de 1934, aparece o primeiro número da revista Brasileira de Pedagogia, órgão oficial da recém-criada Confederação Católica Brasileira de Educação (CARVALHO, 2003, p. 113). 
11 Foram elas: a invocação do nome de Deus no preâmbulo do anteprojeto constitucional e o restabelecimento da colaboração entre a Igreja e o Estado. Essas vitórias são imediatamente atribuídas à "consciência dos constituintes" (SCHWARTZMAN et al., 2000, p. 78).

12 Para esse efeito, é indispensável que todo o ensino e toda a organização da escola, como mestres, programas e livros, em todas as disciplinas, sejam regidos pelo espírito cristão sob a direção e a vigilância maternal da Igreja Católica, de modo que a religião seja verdadeiramente fundamento e coroa de toda a instrução, em todos os graus, não só elementar, mas também média e superior (ENCÍCLICA DIVINI ILLIUS MAGISTRI, 1929).

13 Entre outros representantes católicos, constam: Padre Leonel Franca, Jackson de Figueiredo, Alceu Amoroso Lima, Frei Pedro Secondi, Jônatas Serrano, Oliveira Viana, Hamilton Nogueira, Américo Lacombe, Hélio Viana, Edgard da Mata Machado, Fernando Carneiro, Heráclito Sobral Pinto, Tasso da Silveira, Gustavo Corção, Plínio Salgado, Carlos Lacerda, Lúcia Benedetti, Henriqueta Lisboa, Dom Helder Câmara, Clóvis Monteiro, Padre Augusto Magne, Raimundo Bandeira, Nerval de Gouveia, Carlos Chagas Filho, Joaquim da Costa Ribeiro, Francisco Magalhães Gomes, Rui Coutinho (FILHO, 2007).

14 A Igreja Católica, por exemplo, interferiria ativamente em "todo processo de reforma educativa pós-30". Por ser dona de uma rede de escola em todo o País, e consciente de seus interesses como formadora de mentalidades e condutas, concorreria com outros setores da sociedade que, igualmente, se empenhariam em intervir no processo de reformulação (RODRIGUES, 2005, p. 168).

15 A estratégia de mobilização política de Campos não teve resultado imediato, sua outra estratégia, a de estabelecimento de um pacto com a Igreja, parece ter tido permanências e repercussões muito mais profundas. A Igreja Católica deveria oferecer ao novo regime uma ideologia que lhe desse substância e conteúdo moral, sem os quais, intuía Campos, ele não conseguiria se consolidar (SCHWARTZMAN et al., 2000, p. 61).

16 São as evidências que sugerem que Capanema assumiu o Ministério da Educação e Saúde como parte do acordo geral que então se estabeleceu entre a Igreja e o regime de Vargas, proposto anos antes por Francisco Campos. A parte visível deste acordo foi aprovação, pela Assembleia Constituinte de 1934, das chamadas "emendas religiosas" (SCHWARTZMAN et al., 2000. p. 65).

17 Ao longo do Estado Novo e mesmo antes, Alceu foi o principal interlocutor da Igreja Católica com o Ministério da Educação e Saúde Pública. Defendendo a catolicidade como traço marcante do caráter nacional do brasileiro, nenhum avanço poderia ocorrer em qualquer área, caso não se respeitasse a fé religiosa e a incluísse nas principais instituições sociais (CURY, 1999, p. 42).

18 O padre jesuíta foi assistente eclesiástico dos principais órgãos católicos, com expressiva produção na imprensa católica em torno da restauração da Igreja Católica, sendo nomeado o primeiro reitor da Pontifícia Universidade Católica do Rio de Janeiro PUC, além de ocupar inúmeros cargos entre os aparatos estatais no governo de Getúlio Vargas (FÁVERO; BRITTO, 1999).

19 No Brasil, durante a ditadura do Estado Novo, o ensino secundário foi reestruturado pela Reforma Capanema (1942), que Ihe prescreveu uma cultura escolar marcada pelo retorno das humanidades, pela nacionalização e pela permanência do método "tradicional". Essa reforma, que deixou dois ciclos para o ensino secundário - o ginasial e o colegial -, determinou o ensino de Latim em todas as cinco séries do primeiro ciclo, diferenciandose da Reforma Francisco Campos (1931), que previa essa língua morta somente nas duas últimas séries desse período do ensino secundário e havia tonificado as disciplinas vinculadas às Ciências Naturais (DALLABRIDA, 2014, p. 408). 
20 Consiste no que os indivíduos fazem com o que recebem, e que é uma forma de invenção, de criação e de produção desde o momento em que se apoderam dos textos ou dos objetos recebidos. Desta maneira, o conceito de apropriação pode misturar o controle e a invenção, pode articular a imposição de um sentido e a produção de novos sentidos (CHARTIER, 2001, p. 67).

21 A lealdade de Capanema ao seu mentor se manteria tanto quanto possível inalterada nos próximos onze anos de ministério. "Tudo que combinei com você está na minha memória", escreveria Capanema a Alceu anos mais tarde, a propósito da Faculdade Nacional de Filosofia (SCHWARTZMAN et al., 2000, p. 66).

22 O filósofo (francês) Maritain pode ser considerado um dos mais importantes pensadores católicos no período entre guerras [...] Toda a sua vasta obra, no campo da arte, da política e da metafisica, é perpassada pela preocupação fundamental de descompatibilizar a fé católica com os saberes das ciências positivas (JAPIASSU; MARCONDES, 1996, p. 174).

23 Destacam-se, entre as inúmeras obras de Maritain, Arte e escolástica (na década de 1920); Os graus do saber; Sete lições sobre o ser; Ciência e sabedoria (na década de 1930); Filosofia da natureza; Humanismo integral; Rumos da educação; Cristianismo e democracia; Princípios de uma política humanista (década de 1940); e Elementos de filosofia (década de 1950), que irão constituir, entre os instrumentos teóricos, os aportes para discussões dos intelectuais católicos.

24 De que modo se poderá conciliar a unidade dos cristãos com um pluralismo legitimo em matéria política? É a esta questão delicada e que dirige as posições, que respondem com uma clareza e uma precisão perfeita, Jacques Maritain (A ORDEM, 1937, p. 11). 